EDUCATION

Research, Inovotion and Solutions on Inine $^{8}$

\section{Electronic Journal of Research}

in Educational Psychology

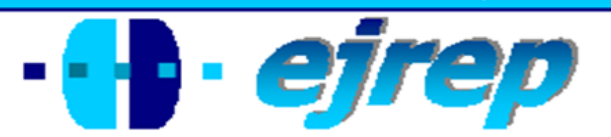

Editorial EOS

\title{
Self-Efficacy, Gender and Trait Anxiety as Moderators of Test Anxiety
}

\author{
Euckay U. Onyeizugbo
}

Department of Psychology, University of Nigeria, Nsukka

Nigeria

Correspondence: Euckay U. Onyeizugbo. Department of Psychology, University of Nigeria, Nsukka. Nigeria. E-mail: euckieo@yahoo.com, euckay@unn-edu.net

(C) Education \& Psychology I+D+i and Editorial EOS (Spain) 


\section{Abstract}

Introduction. Test anxiety inhibits students from performing according to their full potential in academic setting.

Objectives. This study investigated self-efficacy, gender and trait anxiety as moderators of test anxiety.

Method. Two hundred and forty nine (249) psychology majors drawn from a university in Eastern Nigeria participated in the study. General self-efficacy scale, Westside test anxiety scale and State-Trait Anxiety Inventory, Y-2 were used to assess self-efficacy, test anxiety and trait anxiety respectively. Data collected were analysed using regression analysis, analysis of variance (ANOVA), and Pearson correlation.

Results. Results of regression analysis indicated that the model was significant. Self-efficacy contributed $14 \%$ of the variability in test anxiety, whereas trait anxiety moderated $49 \%$ of the variability in test anxiety. Gender was not a significant predictor of test anxiety. Persons with lower self-efficacy had higher test anxiety scores. Also, self-efficacy correlated negatively with test anxiety, whereas trait anxiety correlated positively with test anxiety.

Conclusions. These findings have implications for developing programs to enhance performance in students who have difficulties with testing situations.

Keywords: Self-efficacy; trait anxiety; gender; test anxiety; university students

Received: 06/15/09 Initial Acceptance: 07/06/09 Definitive Acceptance: 01/11/10 


\section{Auto-eficacia, sexo y rasgo de ansiedad como moderadores de la ansiedad ante exámenes}

\section{Resumen}

Introducción. La ansiedad ante los exámenes inhibe la ejecución de los estudiantes de acuerdo con su potencial académico.

Objetivos. El estudio analiza la autoeficacia, el sexo y el rasgo de ansiedad como moderadores de la ansiedad ante los exámenes.

Método. Un total de 249 estudiantes de asignaturas obligatorias de universidad participaron en el estudio. Para medir los parámetros anteriormente indicados se utilizaron la Escala General de Autoeficacia, la Escala de Ansiedad ante exámenes Westside y el Inventario de EstadoRasgo de Ansiedad Y-2. Los datos se analizaron mediante análisis de regresión, análisis de varianza (ANOVA) y correlación de Pearson.

Resultados. Los resultados del análisis de regresión indican que el modelo era significativo. La autoeficacia contribuía a explicar el $14 \%$ de la varianza de la ansiedad en exámenes en tanto que el rasgo de ansiedad explicaba el 49\%. El sexo no aparece como predictor significativo de la ansiedad en los exámenes. Las personas con bajo sentido de autoeficacia obtenían altas puntuaciones en la medición de la ansiedad en exámenes. Del mismo modo, la autoeficacia correlaciona de forma negativa con las puntuaciones se ansiedad en los exámenes en tanto que, el rasgo de ansiedad correlaciona positivamente.

Conclusiones. Los hallazgos tienen implicaciones para el desarrollo de programas que mejoren la ejecución en estudiantes que experimental dificultades en situaciones de evaluación.

Keywords: Self-efficacy; trait anxiety; gender; test anxiety; university students

Recibido: 15/06/09 Aceptación Inicial: 06/07/09 Aceptación Definitiva: 11/01/10 


\section{Introduction}

Test anxiety is believed to be the trait that predisposes individuals to react negatively to examinations and tests (Keogh \& French, 2001). Similarly, Spielberger and Sarason (1989) defined test anxiety as a situation-specific trait that refers to the anxiety states and worry conditions that are experienced during examinations. Test anxiety generally, is the uneasiness, apprehension, or nervousness felt by students during examinations or tests. Examination, on the other hand, is one of the main methods of assessment in schools at all levels. However, some individuals are so fearful of test or other forms of examination that their performance is impaired. The level of test anxiety can fluctuate over time in response to both internal and external stimulation. In test anxious individuals, some observable behaviors such as perspiration, excessive movement and questioning of instructions, sweaty palms and muscle tension are common during testing situations. Also, there may be disruption or disorganization of effective problem solving and cognitive control, including difficulty in thinking clearly (Freidman \& Bendas-Jacob, 1997).

Sarason (1975) postulated that individuals with test anxiety focus on task irrelevant stimuli that negatively affect their coordination during examination. Again, the origin of test anxiety is explained with learning-deficit model. This model postulates that test anxiety lies not in taking the test but in preparing for the test (Kleijn, Vander-Ploeg, \& Topman, 1994). This model further states that students with high test anxiety tend to have or use inadequate learning or study skills while in the preparation stage of exam taking. However, different factors may contribute to the development of test anxiety. Among them are self-efficacy, gender and trait anxiety.

Lee and Babko (1994) found that when in a difficult situation such as a college type test, students with a strong academic self-efficacy would devote more attention and effort to the task at hand. Therefore, they will try harder and persist longer than those who have lower levels of self-efficacy. Bandura (1997) defined self-efficacy as beliefs in one's own capacity to organize and execute the courses of action required to manage prospective situations. According to Schwarzer (1994) and Bandura (1995) self-efficacy can make a difference to people's ways of thinking, feeling and acting. With respect to feeling, a low sense of self-efficacy is associated with anxiety and helplessness. People with low self-efficacies also harbor pessimistic thoughts about their performance and personal development. In contrast, a strong 
sense of belief in one's self facilitates cognitive processes in multiple contexts influencing the decision making (Grau, Salanova, \& Peiro, 2001). In addition, Ozur and Bandura (1990) argued that it is perceived self-inefficacy in coping with potentially aversive events that makes them fearsome or anxiety producing. Therefore, more test anxious individuals may feel unable to cope. Test anxiety comes from the fear of being overwhelmed. A fear of being overwhelmed comes from the perceptions that one does not have the capacity to cope with the situation one faces (inefficacy). Jing (2007) found a significant negative correlation between test anxiety and self-efficacy. Also, social cognitive theory of Bandura (1997) postulates that human functioning results from interaction among personal factors, for example, cognition, and environmental condition. Self-efficacy affects an individual's task choice, effort and persistence (Schunk, 1995). Compared with students who doubt their capabilities, those who feel self-efficacious about situations are apt to participate more readily, work harder, and persist longer when they encounter difficulties (Bandura, 1997).

Gender could possibly predict differences in levels of test anxiety. Zeidner (1990), and Kessler et al., (1995) found that girls significantly have higher test anxiety than boys. However, Mwamwenda (1993) found no significant gender differences in test anxiety among South African sample. In the present study, gender was also examined to see if it contributed any variability in test anxiety.

Anxiety generally is a physiological and psychological state characterized by cognitive, somatic, emotional and behavioral components (Seligman, Walker \& Rosenhan, 2001). Although anxiety is often detrimental, it may be beneficial if it is not extreme. An optimal amount of anxiety (Simpson, Parker \& Harrison, 1995) can mobilize human beings to respond rapidly and efficiently, while excessive amounts of anxiety may foster poor response and sometimes inhibit response.

According to Spielberger (1983), anxiety can be either a short term (state anxiety) or along term (trait anxiety) phenomenon. State anxiety is an unpleasant emotional arousal in face of threatening demands. A cognitive appraisal of threat is a prerequisite for the experience of this emotion (Lazarus, 1991). Trait anxiety, on the other hand, reflects a stable tendency to respond with anxiety in the anticipation of threatening situations. While test anxiety and trait anxiety may be regarded as subtypes of the same concept, there appear to be conceptual reasons for not viewing them as equivalent. Test anxiety is more of short-term state spe- 
cifically during examinations, whereas trait anxiety reflects a stable tendency to respond with anxiety across situations.

The present study, therefore, hypothesized that variability in the participants' test anxiety will be predicted by the independent variables (self-efficacy, gender and trait anxiety).

\section{Method}

\section{Participants}

Two hundred and forty nine $(n=249)$ psychology majors, who were in their third year in a university in Eastern Nigeria, participated in this study. They included 100 men and 149 women ranging in age from 23-30 ranging in age from 23-30; and 132 persons of lower selfefficacy and 117 persons of higher self-efficacy. In this study, mean score generated from the sample was used to categorize participants into various levels of self-efficacy. Participants who scored below 32 were categorized as lower self-efficacy, whereas those who scored above 32 were categorized as higher self-efficacy.

\section{Instruments}

General Self-efficacy Scale (Jerusalem \& Schwarzer, 1992), State-Trait Anxiety Inventory (STAI, form Y-2: Spielberger, 1983), and Westside Test Anxiety Scale (Driscoll, 2007) were used to collect data for self-efficacy, trait anxiety and test anxiety respectively. The General Self-efficacy Scale was developed to assess a general sense of perceived selfefficacy with the aim to predict coping with daily hassles as well as adaptation after experiencing all kinds of stressful life events. It contains 10 items, and responses are made on a 4point scale ranging from 1-not at all true to 4 - exactly true. Some of the items include: I can always manage to solve difficult problems if I try hard enough; I am confident that I could deal efficiently with unexpected events, etc. It is a unidimensional scale and the author found the Cronbach alphas in many nations to be from .76 to .90. Schwarzer, Bäßler, Kwiatek, Schröder, \& Zhang (1997) found a discriminant validity of -.52 and -.60 by correlating the scale with depression scale by Zerssen (1976) and Anxiety scale by Spielberger (1983) respectively.

State-Trait Anxiety Inventory (STAI, Y-2: Spielberger, 1983) measures trait anxiety, which is the relatively stable predisposition of an individual to being anxious. It contains 20 items with a 4-point response format. The scoring patterns are direct for some items and re- 
verse for others. Spielberger (1983) reported an alpha of .90 and .91 for male and female samples, and a test-retest reliability of .77 .

Westside Test Anxiety Scale is an extremely brief screening instrument meant to identify students with anxiety impairment. It contains 10 items, which are in a five-point scale ranging from 1- not at all true to 5 - extremely true. Some of the items include: the closer I am to a major exam, the harder it is for me to concentrate on the material; when I study, I worry that I will not remember the material on the exam, etc. The author showed the utility of the scale to predict test anxiety in a study of test anxious students who were divided into intervention and control groups (Driscoll, 2007). In the study, Driscoll gave intervention group anxiety-reduction training. Anxiety reduction benefits, as measured by the Westside scale, correlated an average of .44 with the test gain, indicating that changes in the Westside scale accounted for $20 \%$ of the changes in test. Onyeizugbo (2008) found an alpha of .78, split half reliability of .77 in a Nigerian sample.

\section{Procedure}

All the participants in this study were third year students of psychology. The researcher administered the assessment instruments during one of their classes. They were informed that they were going to have a test (quiz). Before the test, they were giving the measures to respond to. The researcher gave each person a 2-page document containing demographic information such as age, sex, etc., and the three measures used for the study. They read the instructions in each measure. They were able to work on the materials in a large hall, with seats well spaced between each person in the hall. They completed the responses within 30 minutes, and the researcher collected the materials immediately.

\section{Design/statistics}

This study adopted an ex-post facto design; regression analysis, analysis of variance and Pearson $r$ was used for data analysis 


\section{Results}

A linear regression analysis using enter method showed a significant model emerged, $\mathrm{F}_{3,245}=32.28, \mathrm{p}<.001$. The adjusted $\mathrm{R}$ square is .27 . The significant variables are shown in table 1

Table 1. Regression analysis summary showing the contributions of self-efficacy and trait anxiety in test anxiety.

\begin{tabular}{ccc}
\hline Predictor variable & Standardized coefficients Beta & Significant \\
Self-efficacy & -.14 & $* *$ \\
Trait anxiety & .49 & $* *$ \\
\hline$* *=p<.01, * * *=p<.001$ (Gender was not a significant predictor in the model).
\end{tabular}

Self-efficacy contributed $14 \%$ of the variance in the model; this is significant $(p<.01)$. Trait anxiety predicted $49 \%$ of test anxiety $(\mathrm{p}<.001)$. Therefore, knowing a student's level of self efficacy and trait anxiety gives one confidence in predicting how test anxious a student becomes.

Further, analysis of variance showed that those with higher self-efficacy have lower test anxiety $($ mean $=2.10$; S.D. $=.60)$ than those with lower self-efficacy $($ mean $=2.53$, S.D. $=.59$ ) as shown in table 2 . The difference is significant $\mathrm{F}=39.67, \mathrm{p}<.001$ (table 3).

Table 2. Mean scores of participants of higher and lower self-efficacy on test anxiety

\begin{tabular}{cccc}
\hline Self-Efficacy & Mean & Std. Deviation & $\mathbf{N}$ \\
\hline Low & 2.53 & .60 & 132 \\
High & 2.10 & .59 & 117 \\
Total & 2.30 & .64 & 249 \\
\hline
\end{tabular}

Table 3. Summary of ANOVA showing influence of self-efficacy on test anxiety

\begin{tabular}{cccccc}
\hline Source & Type III Sum of Squares & df & Mean Square & F & Sig. \\
\hline Corrected Model & 14.00 & 1 & 14.00 & 39.67 & .00 \\
Intercept & 1300.71 & 1 & 1300.71 & 3685.45 & .00 \\
Self-efficacy & 14.00 & 1 & 14.00 & 39.67 & .00 \\
Error & 87.17 & 247 & .35 & & \\
Total & 1422.99 & 249 & & & \\
Corrected Total & 101.18 & 248 & & & \\
\hline
\end{tabular}

a $R$ Squared $=.138$ (Adjusted $R$ Squared $=.135$ ) 
Also, there was a significant negative correlation between self-efficacy and test anxiety scores, $-.24, \mathrm{p}<.001$, and a positive correlation between trait anxiety and test anxiety, .51, $\mathrm{p}<.001$ (table 4) suggesting that high test anxiety is associated with lower self-efficacy, and higher trait anxiety.

Table 4. Correlations between self-efficacy, trait anxiety and test anxiety

\begin{tabular}{ccccc}
\hline & & Self-efficacy & Trait anxiety & Test anxiety \\
\hline Pearson Correlation & Self-efficacy & 1.00 & -.23 & -.24 \\
& Trait anxiety & -.23 & 1.00 & .51 \\
& Test anxiety & -.24 & .51 & 1.00 \\
Sig. (1-tailed) & Self-efficacy &. & .00 & .00 \\
& & & & \\
& Trait anxiety & .00 &. & .00 \\
& Test anxiety & .00 & .00 &. \\
& & & & \\
& Nelf-efficacy & 249 & 249 & 249 \\
& Trait anxiety & 249 & 249 & 249 \\
& Test anxiety & 249 & 249 & 249 \\
\hline
\end{tabular}

\section{Discussion}

As evidenced in the results, self-efficacy significantly predicted $14 \%$ of the variability in test anxiety. This implies that self-efficacy belief of the participants is a potent moderator of test anxiety experienced by the participants. Also self-efficacy has a negative relationship with test anxiety. Students with higher self-efficacy had lower test anxiety and vice versa. The present finding agrees with previous studies (Bandura, 1995; Bandura, 1997; Grau, Salanova \& Peiro, 2001; and Jing, 2007), showing a negative relationship exists between self-efficacy and test anxiety.

Test anxiety involves feelings and cognitions, and social cognitive theory of selfefficacy by Bandura stated that beliefs about the anticipated consequences of events can influence reaction to such events. Also Pajares and Miller (1994) asserted that efficacy beliefs influence the amount of anxiety individuals experience as they engage in an activity. According to Pajares and Schunk (2001), a strong sense of efficacy enhances human accomplishment, and confident individuals approach difficult tasks as challenges to be mastered rather than as threats to be avoided. Conversely, people who doubt their efficacy may believe that things are tougher than they really are, a belief that fosters test anxiety and narrow vision of how best to 
solve a problem. In the environment where this study was conducted, examination fraud is rampant. Many students approach examinations with much anxiety. Based on the findings of negative relationship between self-efficacy and test anxiety, it is possible that many of these students under-rate their capability/ability to study, understand and excel in an examination, consequently, as the author observed in her interaction with students during tests and examinations, many students depend on cheating (e.g., copying from fellow student's work, asking for answers, etc.) to pass their examinations or to obtain higher grades. Since the result showed that $14 \%$ of the variability in test anxiety is moderated by self-efficacy, caregivers in school settings helping those with test anxiety problems might consider programs that can enhance self-efficacy beliefs of their clients.

The outcome of this study failed to show gender as a significant moderator of test anxiety. This is in agreement with the study by Mwamwenda (1993) who found no significant gender differences in test anxiety. Even though Kessler et al., (1995), and Zeidner (1990) found that women are more affected by anxiety disorders than men, this study did not find gender differences in test anxiety. This can be explained by the fact that the world in which we live is changing, and socialization of female and male children is also undergoing radical changes. In society generally, even though women still occupy lower status and are socialized to be soft, dependent on men, etc. (which could explain Kessler et al., findings), in the academic setting, only persons who score above set limits are admitted. So in academia, there is no man or woman so to say, everyone is expected to excel. Given similar intelligence quotient of students, one expects female and male students to face academic challenges with courage and determination. Besides, women in most parts of the world, including Nigeria, are emerging from the "cocoon" that enveloped their forebears for many centuries, and asserting their rights side-by-side their men counterparts (Onyeizugbo, 2003). In fact, in the class from where the participants in this study were drawn, female students are the best $5 \%$ of the class, and many of them are quite confident. So, it is time psychologists look closely at various aspects of human behavior, and if there is a consistent evidence that there no gender differences in most human attributes, then a paradigm shift becomes necessary in the way we conceptualize humans in relation to the biological given; perhaps, emphasis will be placed on what unites, rather than what divides humanity. This, hopefully, will go a long way in ensuring healthy, and respectful peaceful co-existence in society, and the harnessing of the potentials of both men and women for human progress. It is likely that test anxiety is moderated by other factors (e.g. self-efficacy, trait anxiety, etc.) other than gender. 
However, the finding showed that $49 \%$ of the variability in test anxiety is moderated by trait anxiety. Therefore, trait anxiety proves to be a potent predictor of test anxiety. Trait anxiety also had a positive correlation with test anxiety. The result suggests that individuals with trait anxiety might be more susceptible to test anxiety. This could be explained by the fact that trait anxiety is a more enduring personality disposition whereby the person high in trait anxiety is predisposed to approach day-to-day encounter with one's environment, including tests/examinations, in an anxiety-prone manner. Brown and Barlow (2002) found that $55 \%$ of the participants who received a principal diagnosis of an anxiety disorder had at least one additional anxiety disorder at the time of assessment. This is understandable in view of Barlow and Durand's (2005) observation that rates of co-morbidity among anxiety disorders are high; that these disorders share the common features of anxiety; and they also share the same vulnerabilities, biological and psychological, to develop anxiety. They differ only in the focus and patterning of anxiety. However, since trait anxiety is pervasive, in providing assistance for persons diagnosed with test anxiety, further assessment needs to be done to ascertain if trait anxiety is also present in such an individual.

It is suggested that counselors, psychologists and other professionals working in school settings could create special programs for students with test anxiety, which would include a special program (or programs) for enhancing self-efficacy.

Given that a very significant proportion of the variability in test anxiety was predicted by trait anxiety, one wonders whether state anxiety will give a similar or different picture. Subsequent investigations in this domain may want to examine the relative contributions of trait vs. state anxiety in test anxiety. This will be invaluable in developing programs to assist test-anxious students in overcoming their difficulties. 


\section{References}

Bandura, A. (1995). Self-efficacy in changing societies. New York: Cambridge University Press.

Bandura, A. (1997). Self-efficacy: The exercise of control. New York: Freeman.

Barlow, D.H., \& Durand, V.M. (2005). Abnormal psychology: An integrative approach. Belmont, CA: Thomson Wadsworth.

Brown, T.A., \& Barlow, D.H. (2002). Classification of anxiety and mood disorders. In D.H. Barlow, Anxiety and its disorders: The nature and treatment of anxiety and panic. ( $2^{\text {nd }}$ ed.). New York: Guilford Press.

Driscoll, R. (2007). Westside test anxiety scale validation. Education Resources Information center.

Friedman, I. A., \& Bendas-Jacob, O. (1997). Measuring perceived test anxiety in adolescents: A self-report scale. Educational and Psychological Measurement, 57, 1035-1047.

Grau, R., Salanova, M. \& Peiro, J. M. (2001). Moderator effects of self-efficacy on occupational stress. Psychology in Spain, 5(1), 63-74.

Jerusalem, M., \& Schwarzer, R. (1992). Self - efficacy as a resource factor in stress appraisal process. In R. Schwarzer (Ed.), Self-efficacy: Thought control of actions (pp. 195 213). Washington DC: Hemisphere.

Jing, H. (2007). Analysis on the relationship among test anxiety, self-concept and academic competency. US-China Foreign Language, 5(1), 48-51.

Keogh, E. \& French, C.C. (2001). Test anxiety, evaluative stress, and susceptibility to distraction from threat. European Journal of Personality, 15(2), 123 - 141.

Kessler, R.C., Sonnega, A., Bromet, E., Hughes, M., \& Nelson, C.B. (1995). Posttraumatic stress disorder in the national comobidity survey. Archives of General Psychiatry, 52, 1048-1060.

Kleijn,W.C., Vander Ploeg, H. M. \& Topman, R.M. (1994). Cognition, study habits, test anxiety and academic performance. Psychological Reports, 75, $1219-1226$.

Lazarus, R.S. (1991). Emotion and adaptation. London: Oxford University Press.

Lee, C. \& Babko, P. (1994). Self-efficacy beliefs: Comparison of five measures. Journal of Applied Psychology, 79, 364-369.

Mwamwenda, T.S. (1993). Gender differences in test anxiety among South African University Students. Perceptual and Motor Skills, 76(2), 554 
Onyeizugbo, E.U. (2003). Effects of gender, age, and education on assertiveness in a Nigerian sample. Psychology of Women Quarterly, 27, 12 - 16.

Onyeizugbo, E.U. (2008). Validation of Westside Test Anxiety Scale in Nigeria. Unpublished manuscript.

Ozur, E.M. \& Bandura, A. (1990). Mechanisms governing empowerment effects: A self efficacy analysis. Journal of Personality and Social Psychology, 58, 472-486.

Pajares, F. \& Miller, M.D. (1994). The role of self-efficacy and self-concept beliefs in mathematical problem-solving: A path analysis. Journal of Educational Psychology, 86, 193-203.

Pajares, F. \& Shunk, D.H. (2001). Self-beliefs and school success: Self-efficacy, self-concept and school achievement. In R. Riding \& S. Rayner (Eds.) Perception (pp.239-266). London: Abex publishing.

Sarason, I.G. (1975). Test anxiety and the self-disclosing coping model. Journal of Consulting and Clinical Psychology, 43, 148-152.

Schunk, D.H. (1995). Self-efficacy and education and instruction. In J.E. Maddux (Ed.), Selfefficacy, adaption and adjustment: Theory, research and applications (pp.281-303). New York: Plenum.

Schwarzer, R. (1994). Optimism, vulnerability, and self-beliefs as health-related cognitions: A systematic overview. Psychology and Health: An International Journal, 9, 161180.

Schwarzer, R., Bäßler,J., Kwiatek,P., Schröder, K., \& Zhang, J.X. (1997). The assessment of optimistic self - beliefs: Comparison of the German, Spanish, and Chinese versions of the general self-efficacy scale. Applied Psychology: An International Review, 46(1), $69-88$.

Seligam, M.E.P., Walker, E.F. \& Rosenhan, D.L. (2001). Abnormal psychology $\left(4^{\text {th }}\right.$ ed.). New York: W.W.Norton \& Company, Inc.

Simpson, M.L., Parker, P.W. \& Harrison, A. W. (1995). Differential performance on Talyor's manifest anxiety scale in black private college freshmen, a partial report. Perceptual and motor Skills, 80, $699-702$.

Spielberger, C.D. (1983). Manual for the State-Trait Anxiety Inventory (STAI). Palo Alto, CA: Consulting Psychologists press.

Spielberger, C.D., \& Sarason, I.G. (Eds.) (1983). Stress and anxiety (vol.12). Washington: Hemisphere pub. Co. 
Zeidner, M. (1990). Does test anxiety bias scholastic aptitude test performance by gender and sociocultural group? Journal of personality assessment, 55(1-2), 145-160.

Zerssen, D.V. (1976). Depressiveness scale. Weinhelim, Germany: Beltz. 